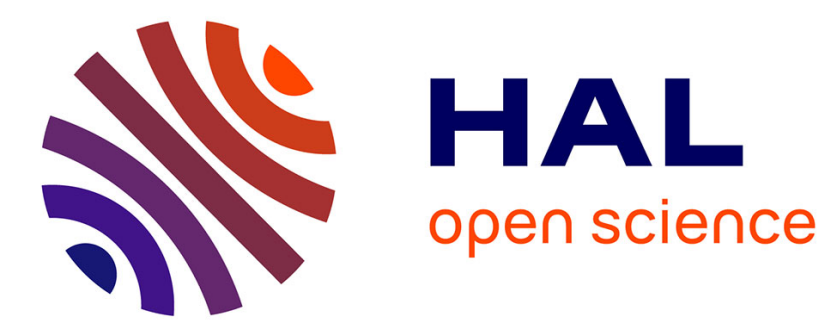

\title{
Modification of metals by high energy excimer laser
}

Th. Sarnet, J. Montagne, G. Inglesakis, M. Autric, L. Barrallier, G. Barreau

\section{To cite this version:}

Th. Sarnet, J. Montagne, G. Inglesakis, M. Autric, L. Barrallier, et al.. Modification of metals by high energy excimer laser. Journal de Physique IV Proceedings, 1994, 04 (C4), pp.C4-69-C4-72. 10.1051/jp4:1994413 . jpa-00252581

\section{HAL Id: jpa-00252581 https://hal.science/jpa-00252581}

Submitted on 1 Jan 1994

HAL is a multi-disciplinary open access archive for the deposit and dissemination of scientific research documents, whether they are published or not. The documents may come from teaching and research institutions in France or abroad, or from public or private research centers.
L'archive ouverte pluridisciplinaire HAL, est destinée au dépôt et à la diffusion de documents scientifiques de niveau recherche, publiés ou non, émanant des établissements d'enseignement et de recherche français ou étrangers, des laboratoires publics ou privés. 


\title{
Modification of metals by high energy excimer laser
}

\author{
Th. SARNET, J.E. MONTAGNE, G. INGLESAKIS, M. AUTRIC, L. BARRALLIER* and \\ G. BARREAU*
}

Institute of Fluid Mechanics - Laser - Matter Interaction Group, Marseille, France

* Ecole Nationale d'Arts et Métiers, Mecasurf Laboratory, Aix-en-Provence, France

\section{Introduction}

In order to improve the mechanical properties of a metallic sample using a pulse laser, two different techniques can be used: direct irradiation (ablation mode) and, confined geometry with a transparent material placed in close contact to the surface. The direct irradiation generally induces a modification of the roughness and sometimes, due to the rapid cooling, a change in the structure and hardness of the surface. The confined geometry uses the propagation of a shock wave in the metal to induce a compressive residual stress field in order to increase the fatigue resistance and wear properties of this material. The majority of the present experiments were carried out using direct irradiation with a large $\mathrm{KrF}$ excimer laser $(200 \mathrm{~J}, 400 \mathrm{~ns})$ built at the Institute by the Laser-Matter Interaction Group. After irradiation, the improvement or decrease in mechanical properties of metals are discussed including some potential applications.

\section{1) Experiments}

Metallic samples have been irradiated by a long-pulse ( $\tau>300 \mathrm{~ns}$ ) $\mathrm{KrF}$ laser. The experiments have been performed with an energy density of 0,3 to $120 \mathrm{~J} / \mathrm{cm}^{2}$ and a power density of 1 to $400 \mathrm{MW} / \mathrm{cm}^{2}$. The samples investigated were pure aluminum (1050 A: 99,5\% $\mathrm{Al})$, aluminum alloy $(2017 \mathrm{~A})$, constructional steel (35NCD16: $0,35 \% \mathrm{C}, 4 \% \mathrm{Ni}, 1,8 \% \mathrm{Cr}$ ) and titanium alloy (Ti6A14V). They were polished to obtain a roughness $10<\mathrm{Ra}<0,08 \mu \mathrm{m}$ and stress-relief heat treated for some stress measurements after irradiation.

After irradiation, changes in the surface properties have been characterized using SEM, roughness analyzers, micro hardness tester and X-Ray Diffraction (XRD) residual stress apparatus.

\section{2) Topography and Roughness}

The evolution of the roughness was studied in order to control this surface process. If the original roughness is relatively low $(\mathrm{Ra}<0,5 \mu \mathrm{m})$, an increase in the roughness is observed with intensity near of $2.10^{8} \mathrm{~W} / \mathrm{cm}^{2}$ for all the samples investigated.

It has been shown 1)2) that a single pulse on a metallic surface accentuates melting at surface discontinuities like scratches, inclusions and impurities leading to an increase in the roughness. Typical craters are generally created around inclusions like silicate, sulfide or alumina ${ }^{3}$.

If the treated material is cast iron, it is possible to form those craters around graphite spherulites. The result is an improvement in the wet behavior of some mechanical parts used in automotive industry 4$) 5$ ).

Hydrodynamical instabilities and turbulences on the liquid metal surface also lead to an increase in the roughness by creating ripples on the final topography 6 ).

It is possible however, to smooth a metallic surface above the ablation threshold. In this way, after polishing an aluminum alloy surface with different grids and diamond pastes, we have irradiated these surfaces with one single pulse and four successive pulses at a fluence of $80 \mathrm{~J} / \mathrm{cm}^{2}$ ( $\tau=300 \mathrm{~ns}$ ). It is interesting to notice the smoothing and roughening 
behavior of this metal at this intensity: by chosing the appropriate number of pulses (Fig. 1) and the energy density (Fig. 2), it appears possible to control the final roughness of the treated sample.
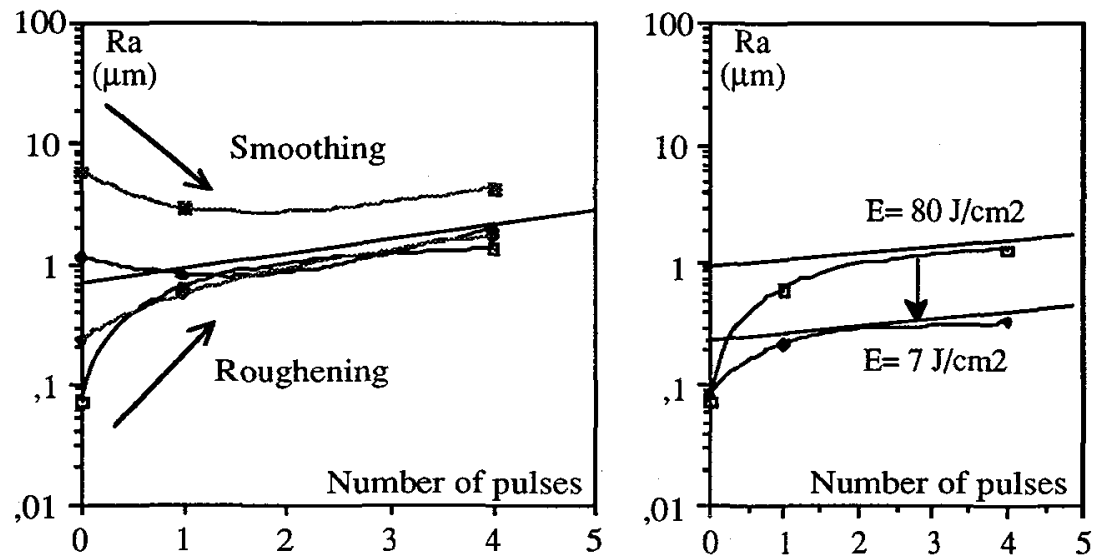

Fig. 1: Experimental evolution of the roughness $\mathrm{Al}$ alloy (2017), $\mathrm{F}=80 \mathrm{~J} / \mathrm{cm}^{2}$

Fig, 2: Same evolution, different fluence. $\left(\mathrm{F}=7\right.$ and $\left.80 \mathrm{~J} / \mathrm{cm}^{2}\right)$

This behavior appears interesting for the pre-adhesion treatment of metals when a specific roughness is wanted. It has also been shown ${ }^{7)}$ that this roughness and the presence of oxide (i.e. sample was treated in air) lead to a high enhancement of the absorptivity of metals at $10.6 \mu \mathrm{m}$. The $\mathrm{CO}_{2}$ laser drilling efficiency can be improved: a relatively low intensity $\left(10^{6}\right.$ instead of $\left.10^{7} \mathrm{~W} / \mathrm{cm}^{2}\right)$ and a reduced gas flow become sufficient to treat these highly reflective metal surfaces pre-treated by a series of overlapping excimer laser pulses.

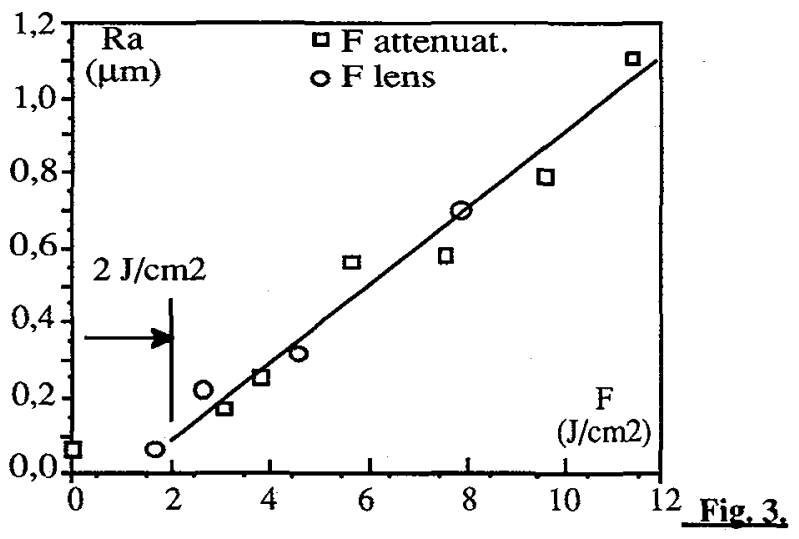

Figure 3 shows the evolution of the roughness versus fluence, this experiment has been carried out with a commercial Lambda Physics LPX 210 Excimer Laser, at a wavelength of $248 \mathrm{~nm}$, using a UV attenuator ( $\mathrm{F}$ attenuat.) and different position of the focusing lens ( $F$ lens) to change the fluence. The threshold fluence for ablation appears to be approximately $\mathrm{F}=2 \mathrm{~J} / \mathrm{cm}^{2}$. 


\section{3) Structure and Hardness}

The eventual changes of the surface hardness have been measured with a Leitz micro hardness tester with a Vickers indenter operating with a load of $100 \mathrm{~g}$ (Fig. 4). The pure aluminum samples reveal no important change of the original low hardness, whereas a softening of the aluminum alloy occurs after a single pulse.

This decrease in hardness can be a result of the thermal annealing of the material without formation of a metastable phase, or a precipitate, thereby a much softer material surface. Also micro cracks, as observed by SEM on the surface, can explain the absence or decrease in hardening for these materials.

However, a significant hardening has been observed on the $35 \mathrm{NCD} 16$ steel sample (quenched at $850^{\circ} \mathrm{C}$, tempered at $600^{\circ} \mathrm{C}, \sigma_{\mathrm{TS}}=1200 \mathrm{MPa}$ ) and can be correlated with the fine martensitic structure obtained after irradiation and revealed by SEM photographs.

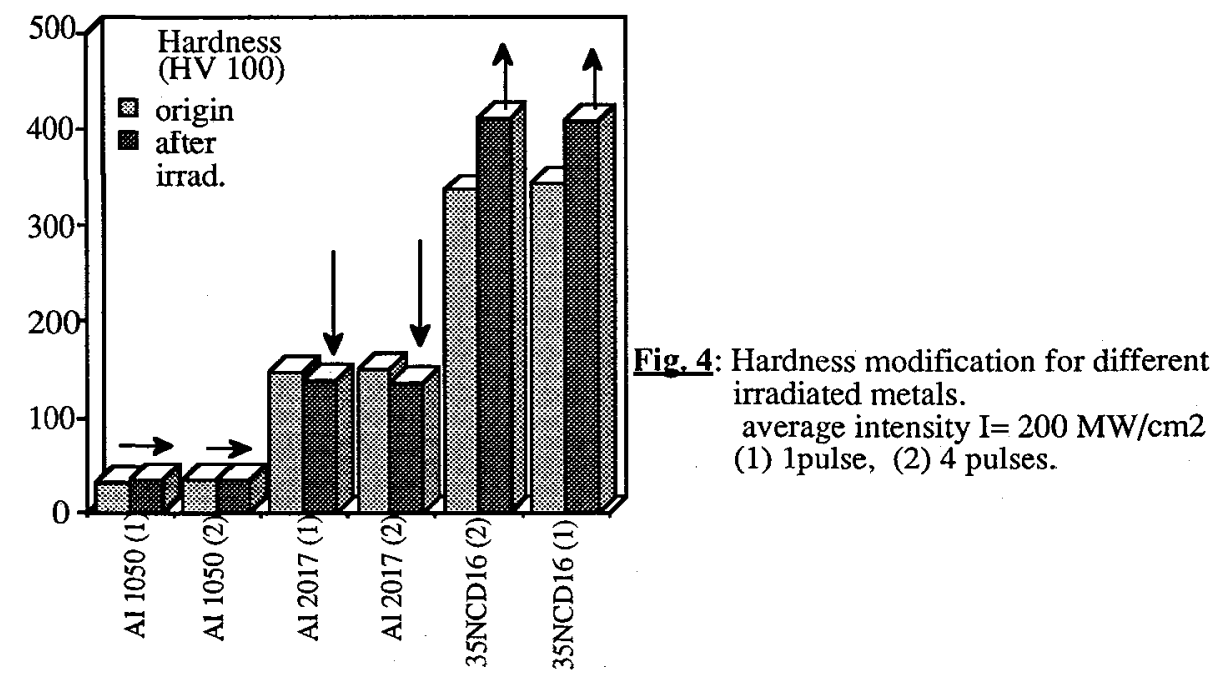

Cross-sections of the samples shows that the depth of the affected zone is of the order of 3-4 $\mu \mathrm{m}$. This evolution of the hardness is the same (about $20 \%$ higher) for one single pulse and four successive pulses.

\section{4) Residual Stress Field}

Using the X-Ray diffraction method, in-depth profiles of residual stresses, have been carried out to determine if the fatigue resistance and the wear of these metals could be improved by this process ${ }^{8)}$. The objective was to increase the life time of industrial products. In this case, it is important to introduce significant compressive residual stresses on the sample surface.

The results obtained for all the samples (Fig 6) show that an important tensile residual stress field is, however, induced onto the surface after a single pulse. Figure 6 shows a typical in-depth profile of residual stress induced on a steel sample by this process.

The following explanation of this phenomenon ${ }^{9}$ ) has been given: the heat-affected zone is subject to thermal expansion and is plastically strained by the surrounding material during the heating phase; contrary to the thermal expansion, this compressive deformation is irreversible so, during the rapid cooling, this zone tends to occupy a smaller volume: the surrounding material reacts to the change of the volume by inducing this tensile residual stress field. 


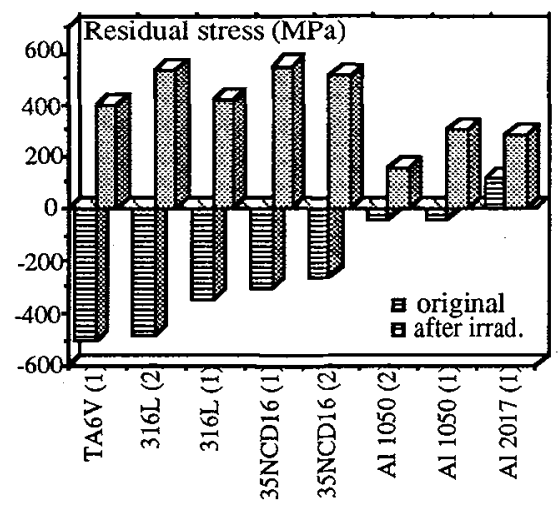

Fig. 5: Residual stresses induced on the irradiated surfaces measured by X Ray Diffraction, Average intensity $\mathrm{I}=200$ $\mathrm{MW} / \mathrm{cm}^{2}, \lambda=248 \mathrm{~nm}$.

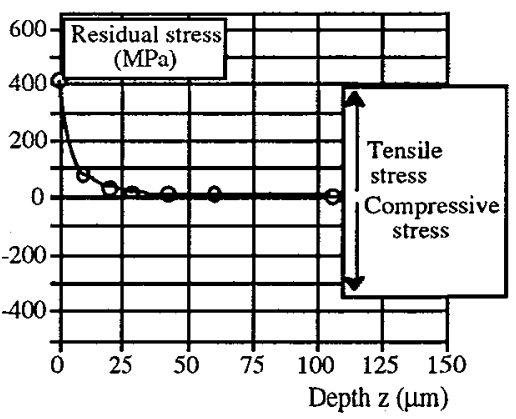

Fig. 6: In-depth profile of a residual stress field induced on a constructional steel (35NCD16), after a direct irradiation. $\mathrm{I}=200 \mathrm{MW} / \mathrm{cm}^{2}, \lambda=248 \mathrm{~nm}$.

\section{Conclusions}

Metallic samples, such as aluminum alloys, titanium alloys, steels, have been irradiated with an excimer laser at a wavelength of $248 \mathrm{~nm}$. The improvement or decrease in the mechanical properties of these metallic samples and some potential applications for the industry, are discussed in this paper. It is possible to control the final roughness of a metallic sample just by changing the incident fluence and the number of pulses. The result can be either to smooth or to increase the original roughness. Due to a thermal effect, the stress induced on the surface is a tensile residual stress field and must be taken into account for eventual industrial applications.

\section{Acknowledgements}

The authors wish to thank Jacky Bouesc for helpful technical assistance during the experiments. The authors also gratefully acknowledge all the MecaSurf Laboratory Technical Staff and Aleka Manousaki from the FORTH Laboratory, Crete, for additional experiments and discussions.

\section{$\underline{\text { References }}$}

1) A. S. Bransden, J.H.P.C. Hegaw, P.H. Balkwill, C. Westcott, (1990) Journ. of Mod. Opt. Vol. 37, 813.

2) J-E. Montagne, T. Sarnet, C. Prat, G. Inglesakis, M. Autric, (1993) Appl. Surf. Science, Vol. 69, 108-114.

3) T. Sarnet, J-E. Montagne, C. Prat, G. Inglesakis, M. Autric and L. Barrallier, G. Barreau, (1993) Proceedings of "International Congress on Applications of Lasers and ElectroOptics ICALEO ' 93", Orlando, Florida USA.

4) C. Papaphilippou, A. Fontes, B. Dubrujeaud, M. Vardavoulias, M. Jeandin, (1993) Proc. 6th International Conf. on Tribology, Budapest, Hungary.

5) E. Schubert, R. Queitsch, H.W. Bergmann, K. Schutte, (1993) Proc. Eureka International Workshop on Excimer Lasers, Erlangen, Germany.

6) L. Nanai, I. Hevesi, F.V. Bunkin, B. Luk'yanchuk, E.A. Morosova, (1987) J. Appl. Phys. Vol. 61, 2633.

7) G. Kinsman, W.W. Duley, (1990) Appl. Phys. Lett., Vol. 56, 996.

8) A.H. Clauer, B.P. Fairand, (1979). "Applications of lasers in material processing", Metzbower, ed.

9) J. Fournier, (1989) Thesis Ecole Polytechnique p.76. 